\title{
Ekspresi Caspase-3 pada Kanker Payudara Tikus Setelah Pemberian Antikanker Brusein-A
}

\author{
Muhartono, ${ }^{\mathbf{1}}$ Subeki $^{2}$ \\ ${ }^{1}$ Bagian Patologi Anatomi, Fakultas Kedokteran, ${ }^{2}$ Fakultas Pertanian, \\ Universitas Lampung, Bandar Lampung, Indonesia
}

\begin{abstract}
Abstrak
Brusein-A diduga menyebabkan apoptosis. Salah satu protein yang berperan dalam proses apoptosis adalah caspase-3. Penelitian ini bertujuan mengetahui aktivitas antikanker brusein-A terhadap ekspresi caspase-3 pada kanker payudara. Penelitian menggunakan rancang acak lengkap. Sebanyak 27 ekor tikus betina berumur 12 minggu diberi dimethylbenzanthracene (DMBA) $20 \mathrm{mg} / \mathrm{kgBB}$ per oral selama 3 minggu sampai terbentuk kanker payudara. Selanjutnya, dibagi dalam 9 kelompok perlakuan brusein-A, yaitu 0; 2,5; 5; 7,5; 10; 12,5; 15; 17,5; dan $20 \mathrm{mg} / \mathrm{L} \mathrm{selama}$ 28 hari. Parameter yang diukur adalah ekspresi caspase-3 yang dinilai berdasar atas persentase sitoplasma yang berwarna coklat. Penelitian ini dilakukan di Laboratorium Patologi-Anatomi dan Laboratorium Biokimia, Pusat Penelitian Ilmu Pengetahuan dan Teknologi (Puspiptek) Serpong tahun 2015-2016. Hasil penelitian menunjukkan ekspresi caspase-3 rata-rata pada dosis o mg/L sebesar 4\%, 2,5 mg/L sebesar 15,3\%, $5 \mathrm{mg} / \mathrm{L}$ sebesar 21\%, 7,5 mg/L sebesar 25\%, $10 \mathrm{mg} / \mathrm{L}$ sebesar 41\%, 12,5 mg/L sebesar 65\%, $15 \mathrm{mg} / \mathrm{L}$ sebesar 75,3\%, 17,5 mg/L sebesar 84\%, dan 20 $\mathrm{mg} / \mathrm{L}$ sebesar 94,7\%. Hasil uji one way ANOVA menunjukkan perbedaan ekspresi caspase-3 rata-rata yang signifikan antarkelompok perlakuan ( $\mathrm{p}=0,0001)$. Uji korelasi Spearman menunjukkan hubungan yang sangat erat dan positif antara dosis brusein-A dan ekspresi caspase-3 $(\mathrm{r}=0,994)$. Simpulan, brusein-A meningkatkan ekpresi caspase-3 pada kanker payudara tikus yang diinduksi DMBA.
\end{abstract}

Kata kunci: Brusein-A, caspase-3, kanker payudara

\section{Caspase-3 Expression on Breast Cancer Rats After Brusein-A Administration}

\begin{abstract}
Brusein-A is thought to cause apoptosis. Caspase- 3 is a protein that plays a role in the process of apoptosis. This study aims to determine anticancer activity of brusein-A on the expression of caspase- 3 in breast cancer. This study uses a completely randomized control design. A total of 27 female rats, 12 week aged, were given $20 \mathrm{mg}$ dimethylbenzanthracene (DMBA)/kgBW peroral for 3 weeks until they had breast cancer. They divided into 9 treatment group of brusein A, that were $0,2.5,5,7.5,10,12.5,15,17.5$, and $20 \mathrm{mg} / \mathrm{L}$ for 28 days. Parameter measured were caspase- 3 expression, assessed on the percentage of brown cytoplasm. This research was conducted in Pathology-Anatomy Laboratory and Biochemistry Laboratory, Research Center for Science and Technology (Puspiptek) Serpong in 2015-2016. The results showed caspase expression rate of $4 \%, 15.3 \%, 21 \%, 25 \%, 41 \%, 65 \%, 75.3 \%, 84 \%$, and $94.7 \%$ on the dosage of , 2.5 , $5,7.5,10,12.5,15,17.5$, and $20 \mathrm{mg} / \mathrm{L}$ respectively. The one way ANOVA test results showed significant difference of caspase-3 expression between treatment group ( $\mathrm{p}=0.0001)$. Spearman's rank correlation test showed that a very close and positive relationship between brusein-A dose and caspase- 3 expression ( $\mathrm{r}=0.994)$. In conclusion, brusein-A increased caspase-3 expression in DMBA induced breast cancer rats.
\end{abstract}

Key words: Breast cancer, brusein-A, caspase- 3

Received: 8 March 2017; Revised: 20 November 2017; Accepted: 8 December 2017; Published: 27 December 2017

Korespondensi: Dr. dr. Muhartono, S.Ked., M.Kes., Sp.P.A. Bagian Patologi Anatomi, Fakultas Kedokteran, Universitas Lampung. Jln. Prof. Dr. Ir. Sumantri Brojonegoro No. 1, Gedung Meneng, Bandar Lampung 35145, Lampung, Indonesia. Telepon: (0721) 7691197. Faksimile: (0721) 7691197. HP: 081272358340.E-mail: dmuhartono@yahoo.com 


\section{Pendahuluan}

Caspase berperan sebagai protein eksekutor yang memutuskan sel untuk apoptosis. Caspase yang belum aktif merupakan procaspase. Agar caspase berfungsi maka harus mengalami aktivasi dengan pemotongan sisi karboksil dan juga pemotongan sisi terminal amino sehingga sisinya menempel sedemikian rupa dan menjadi caspase aktif. Ada stimulus tertentu yang mengubah procaspase menjadi caspase. Caspase-3 termasuk golongan caspase eksekutor yang diaktifkan oleh caspase inisiator, misalnya caspase-8 dan caspase-9. Aktivasi apoptosis baik jalur ekstrinsik maupun intrinsik akan berujung pada aktivasi caspase-3 sebagai caspase eksekutor. Apabila caspase-3 telah teraktivasi maka akan terjadi kematian sel berupa apoptosis. ${ }^{1}$

Mekanisme pemicu terjadi apoptosis dapat disebabkan oleh radiasi, cell stress, infeksi virus, death receptors, granzymes atau obat antikanker seperti kemoterapi. ${ }^{2}$ Obat antikanker itu sering dikembangkan dengan memacu apoptosis pada sel kanker, seperti pada kanker payudara. Salah satu alternatif adalah dengan memanfaatkan senyawa brusein-A yang diisolasi dari buah makasar (Brucea javanica). Beberapa penelitian sebelumnya telah menunjukkan bahwa senyawa quassinoid dari tanaman ini mempunyai aktivitas antitumor. ${ }^{3-5}$ Senyawa golongan quassinoid itu dapat menginduksi apoptosis sehingga terjadi degradasi DNA menjadi rantai oligonukleosom. ${ }^{6}$

Penelitian kami sebelumnya membuktikan bahwa senyawa brusein-A yang diisolasi dari buah makasar menunjukkan aktivitas antikanker secara in vitro terhadap kanker payudara dengan nilai IC50 0,54 mg/L tidak berbeda nyata dengan standar obat cisplatin yang mempunyai nilai

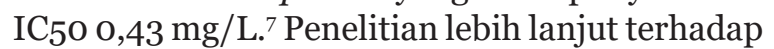
senyawa brusein-A yang dikapsulasi oleh liposom menunjukkan peningkatan aktivitas antikanker dengan nilai IC50 sebesar 0,39 mg/L. ${ }^{8}$ Pemberian senyawa brusein-A yang dikapsulasi liposom pada dosis $10 \mathrm{mg} / \mathrm{kgBB}$ tidak menyebabkan kerusakan hati dan ginjal mencit dengan kadar SGPT 21,67 IU/L dan kadar SGOT 40,67 IU/L. Pemberian senyawa brusein-A yang dikapsulasi liposom pada dosis $10 \mathrm{mg} / \mathrm{kgBB}$ mampu mematikan sel kanker payudara pada mencit. ${ }^{9}$

Secara in vitro ternyata senyawa brusein-A yang dikapsulasi liposom mempunyai aktivitas antikanker yang lebih tinggi dibanding dengan obat standar cisplatin. Secara in vivo senyawa
brusein-A dapat mematikan sel kanker payudara pada mencit sehingga perlu dikaji lebih lanjut mekanisme apoptosis senyawa itu. Brusein-A kemungkinan besar bersifat sitotoksik terhadap pertumbuhan sel kanker payudara dengan cara meningkatkan aktivitas caspase-3 itu sehingga menyebabkan apoptosis. ${ }^{10}$

\section{Metode}

Penelitian ini diawali dengan proses produksi senyawa brusein-A dari buah makasar sesuai dengan prosedur dari Subeki dkk. ${ }^{6}$ Selanjutnya, untuk dapat membuktikan bahwa senyawa yang diperoleh adalah brusein-A maka dilaksanakan analisis spektroskopi IR, MS, dan NMR serta dibandingkan dengan standar brusein-A.

Perlakuan hewan coba sebagai berikut: tikus betina umur 12 minggu dikelompokkan menjadi 9 kelompok dan tiap-tiap kelompok terdiri atas 3 ekor yang ditempatkan dalam kandang terpisah serta diberikan makan dan minum ad libitum. Sebelum tikus diperlakukan, tikus diadaptasikan dalam lingkungan percobaan selama 7 (tujuh) hari. ${ }^{9}$ Semua kelompok tikus diberikan senyawa dimethylbenzanthracene atau DMBA secara oral dengan dosis $20 \mathrm{mg} / \mathrm{kg}$ bobot seminggu dua kali selama 3 minggu agar terbentuk kanker payudara pada tikus.

Selanjutnya, brusein-A diberikan secara oral pada tiap-tiap kelompok tikus dengan dosis masing-masing $0 ; 2,5 ; 5 ; 7,5 ; 10 ; 12,5 ; 15 ; 17,5$; dan $20 \mathrm{mg} / \mathrm{kg}$ bobot sehari sekali selama 7 hari berturut-turut. Satu kelompok tikus digunakan sebagai kontrol tanpa pemberian brusein-A. Perlakuan itu disusun dalam rancangan acak lengkap dengan tiga ulangan. Selanjutnya, tikus dipelihara selama 28 hari dan diberikan makan minum ad libitum, kemudian diperiksa jaringan kanker payudara mempergunakan pemeriksaan imunohistokimia caspase-3.

Ekspresi caspase-3 itu dinilai persentasenya dengan menghitung sel-sel kanker yang terwarnai berwarna coklat pada sitoplasmanya dengan selsel kanker yang tidak terwarnai pada mikroskop dengan pembesaran $400 \times$.

Penelitian ini dilaksanakan di Laboratorium Komponen Bioaktif, juga Laboratorium Patologi Anatomi dan Laboratorium Biokimia, di Pusat Penelitian Ilmu Pengetahuan dan Teknologi (Puspiptek) Serpong. Penelitian ini berlangsung selama 2 tahun, yaitu tahun 2015 sampai dengan tahun 2016. Penelitian ini telah mendapatkan 
persetujuan Komisi Etik Penelitian Kesehatan dari Fakultas Kedokteran Universitas Lampung melalui surat Nomor: 3185/UN26.8/DL/2016.

\section{Hasil}

Hasil isolasi senyawa brusein-A yang diisolasi dari buah makasar mempunyai bentuk tepung amorphous, titik lebur $271-272^{\circ} \mathrm{C}$ dan optikal rotasi $[\alpha]^{20} \mathrm{D}-80,3^{\circ}$ (c 0,8 , piridin). Analisis IR menunjukkan gugus hidroksi $\left(3.420 \mathrm{~cm}^{-1}\right)$, $\delta$-lakton dan ester $\left(1.736 \mathrm{~cm}^{-1}\right)$, serta $\alpha, \beta$-karbonil ikatan rangkap (1.683 dan $1.680 \mathrm{~cm}$ ). Hasil analisis mass spectrophotometer FD-MS: $m / z$ $522[\mathrm{M}]^{+}$dan HR-EI-MS $\mathrm{m} / \mathrm{z} 522.2090[\mathrm{M}]^{+}$ yang menunjukkan rumus molekul $\mathrm{C}_{26} \mathrm{H}_{34} \mathrm{O}_{11}$.

Analisis proton ${ }^{1} \mathrm{H}$-NMR memperlihatkan spektrum resonansi satu metil tersier $(\delta 1,22)$, dua metil sekunder $(\delta 0,90$ dan 0,91$)$, dan satu metil olefinik (1,72). Analisis karbon ${ }^{13} \mathrm{C}$ NMR memberikan spektrum resonansi pada C-3 ( $\delta$ 144,2), C-11 ( $\delta$ 71,5), dan C-12 ( $\delta$ 74,7) yang memperlihatkan terdapat gugus hidroksi yang terikat pada karbon. Rantai samping itu mengandung gugus 3-methylbutanoyloxy yang berhubungan dengan $\mathrm{C}-15$ berdasar atas hasil analisis ${ }^{13} \mathrm{C}$ NMR $(\delta$ 170,0; 42,6; 25,4; 22,3; dan $22,4)$. Struktur kimia brusein-A disajikan pada Gambar 1.

Hasil penelitian memperlihatkan pada dosis o mg/L ekspresi caspase-3 rata-rata sebesar

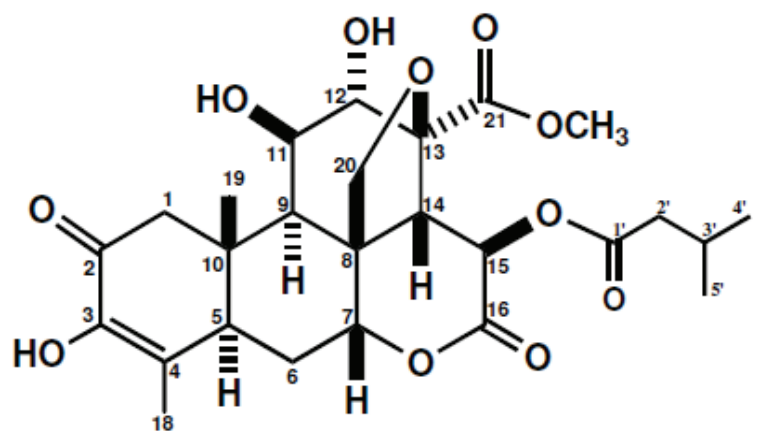

\section{Gambar 1 Struktur Kimia Brusein-A dari Buah Makasar}

4\%, dosis 2,5 mg/L sebesar $15,3 \%$, dosis $5 \mathrm{mg} / \mathrm{L}$ sebesar 21\%, dosis 7,5 mg/L sebesar 25\%, dosis $10 \mathrm{mg} / \mathrm{L}$ sebesar $41 \%$, dosis $12,5 \mathrm{mg} / \mathrm{L}$ sebesar $65 \%$, dosis $15 \mathrm{mg} / \mathrm{L}$ sebesar $75,3 \%$, dosis 17,5 $\mathrm{mg} / \mathrm{L}$ sebesar $84 \%$, dan dosis $20 \mathrm{mg} / \mathrm{L}$ sebesar 94,67\% (Gambar 2). Hasil uji one way ANOVA menunjukkan perbedaan ekspresi caspase-3 ratarata yang signifikan antara kelompok perlakuan $(\mathrm{p}=0,0001)$. Hasil uji lanjut menggunakan uji beda nyata terkecil (BNT) didapatkan perbedaan yang signifikan pada semua kelompok perlakuan (Gambar 2).

Hasil uji korelasi Spearman menunjukkan hubungan yang sangat erat antara peningkatan dosis brusein-A dan ekspresi caspase-3 $(\mathrm{r}=0,994)$. Hubungan yang terjadi bernilai positif. Hal ini

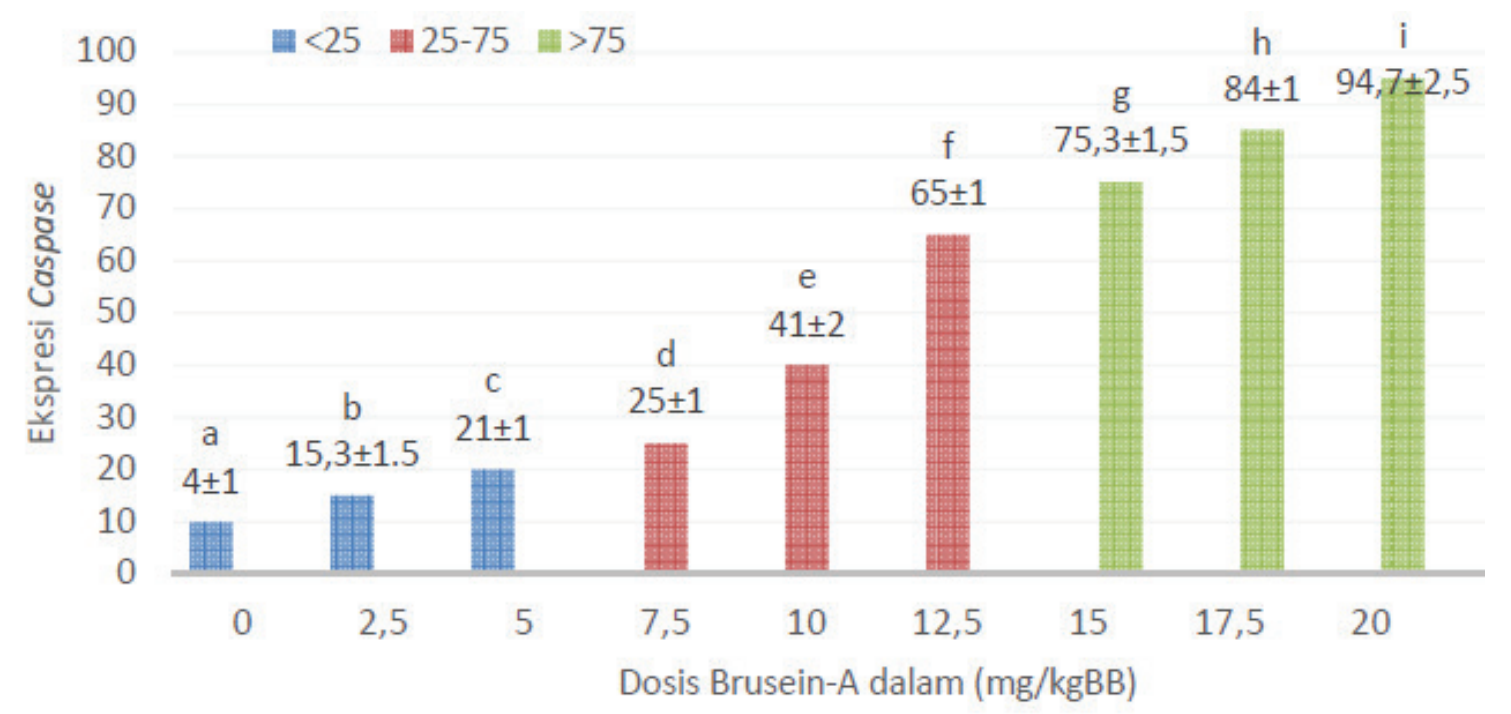

Gambar 2 Ekspresi Caspase-3 Rata-rata pada Berbagai Dosis Brusein-A

Nilai rata-rata yang diikuti dengan huruf yang sama tidak berbeda nyata berdasar atas uji BNT dengan $\alpha=5 \%$ 
memperlihatkan semakin tinggi dosis brusein-A yang diberikan maka akan semakin tinggi nilai caspase-3 yang terekspresi.

\section{Pembahasan}

Terdapat pengaruh akibat pemberian senyawa brusein-A terhadap ekspresi caspase-3 itu yang merupakan marker untuk aktivitas apoptosis pada kanker payudara tikus. Hal ini mendukung berbagai penelitian yang mengemukakan bahwa brusein-A memiliki aktivitas antikanker dengan cara menginduksi apoptosis. Penelitian ini juga memperlihatkan bahwa brusein-A mempunyai efek yang sejalan dengan senyawa isoflavon baik itu genistein maupun daidzein terhadap efek antikanker yang ditimbulkan. Ekstrak kedelai menginduksi tingkat apoptosis yang lebih tinggi dibanding dengan genistein dan daidzein pada jaringan kanker prostat dan hati. ${ }^{11,16}$

Membran mitokondria itu yang melepaskan faktor yang penting seperti sitokrom-c merupakan kunci berlangsungnya jalur apoptosis intrinsik. Reactive oxygen species (ROS) terdapat di dalam dan di sekitar mitokondria dan dikenal sebagai produk sampingan dari proses oksidatif seluler normal. Reactive oxygen species diindikasikan dapat meregulasi inisiasi sinyal apoptosis. ${ }^{12}$

Brusein-A itu dapat menginduksi apoptosis dengan menghasilkan ROS bersamaan dengan gangguan potensial pada membran mitokondria, down-regulasi bcl-2, dan juga up-regulasi bax sehingga menyebabkan mitokondria melepaskan sitokrom-c ke dalam sitosol yang mengaktivasi caspase-9 dan juga caspase-7. Caspase-9 yang teraktivasi menimbulkan asumsi bahwa aktivitas apoptosis yang diinduksi oleh brusein-A terjadi

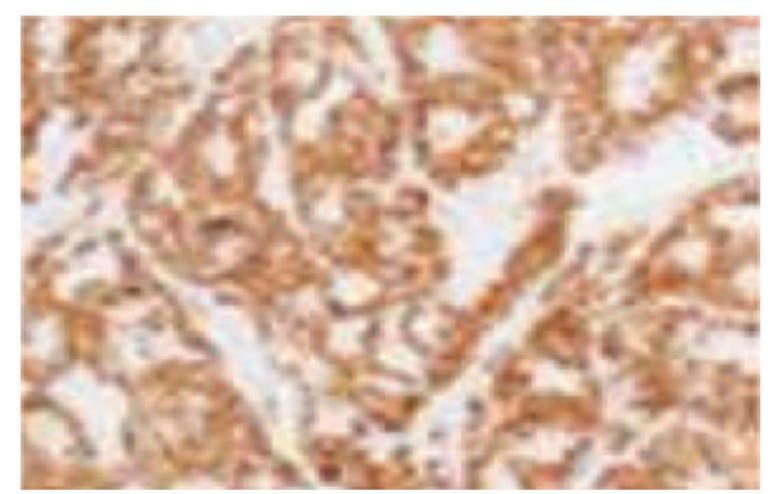

Gambar 3 Hasil Pewarnaan Imunohistokimia Ekspresi Caspase-3 melalui jalur intrinsik atau jalur mitokondria. Pemberian brusein-A dengan cara meningkatkan ekspresi caspase-3 merupakan penanda untuk aktivitas apoptosis pada kanker payudara tikus. ${ }^{13}$

Brusein-A merupakan quassinoid golongan triterpen yang berperanan sebagai antikanker. Sebagai antikanker, senyawa brusein-A memiliki kemampuan berikatan dengan DNA sehingga memengaruhi gen $c-M y c$ dan dapat menginduksi apoptosis. Selain itu, senyawa brusein-A juga dapat menghambat nuclear factor kappa $B$ (NF$\kappa \mathrm{B})$. Dengan demikian, dapat dikatakan bahwa ekstrak buah makasar memiliki aktivitas sebagai antiproliferatif maupun proapoptosis terhadap karsinoma. Efek sitotoksik ekstrak buah makasar dapat menyebabkan fragmentasi DNA sehingga menyebabkan apoptosis. ${ }^{14}$

Apoptosis yang rendah itu berkaitan dengan prognosis yang buruk. Apoptosis itu mengalami peningkatan pada tumor ganas yang diikuti dengan aktivitas proliferasi yang tinggi. Hal ini menunjukkan bahwa kontrol antara proliferasi dan apoptosis harus selalu diperhatikan. Dalam mengevaluasi pertumbuhan dan pengurangan massa tumor itu terhadap respons kemoterapi, radioterapi, dan juga terapi hormonal diperlukan penilaian apoptosis serta proliferasi. ${ }^{15}$

\section{Simpulan}

Brusein-A itu meningkatkan ekspresi caspase-3 pada kanker payudara tikus yang dilakukan induksi dimethylbenzanthracene (DMBA).

\section{Daftar Pustaka}

1. Fan TJ, Han LH, Cong RS, Liang J. Caspase family proteases and apoptosis. Acta Biochim Biophys Sin (Shanghai). 2005;37(11):719-27.

2. Ghobrial IM, Witzig TE, Adjei AA. Targeting apoptosis pathways in cancer therapy. CA Cancer J Clin. 2005;55(3):178-94.

3. Lee KH, Imakura Y, Sumida Y, Wu RY, Hall IH, Huang HC. Antitumor agents. 33. Isolation and structural elucidation of bruceoside-A and -B, novel antileukemic quassinoid glycosides and bruceine-D and -E from Brucea javanica. J Org Chem. 1979;44(13):2180-5.

4. Fukamiya N, Okano M, Miyamoto M, Tagahara K, Lee KH. Antitumor agents. 127. Bruceoside $\mathrm{C}$, a new cytotoxic quassinoid glucoside, and related compounds from Brucea javanica. J Nat Prod. 1992;55(4):468- 
75 .

5. Rachmani EPN, Suhesti TS, Widiastuti R, Aditiyono. The breast of anticancer from leaf extract of annona muricata against cell line in T47D. Int J Appl Sci Technol. 2012;2(1):15764.

6. Subeki, Matsuura H, Takahashi K, Nabeta K, Yamasaki M, Maede Y, dkk. Screening of some indonesian medicinal plants for antibabesial activity and isolation of new quassinoids from Brucea javanica. $J$ Nat Prod. 2007;70(10):1654-7.

7. Ningrum SM. Kajian aktivitas antikanker senyawa brusein-A dari buah makasar (Brucea javanica) terhadap sel kanker payudara (T47D) (skripsi). Bandar Lampung: Fakultas Pertanian Universitas Lampung; 2010.

8. Subeki, Setyaningrum E, Rudiyanto W. Aktivitas antikanker senyawa brusein-a buah makasar (Brucea javanica) terhadap sel kanker payudara (T47D). Dalam: Hendri J, Utomo SD, Susanto GN, Asmi D, Warsono, Subeki, dkk. Prosiding seminar nasional sains dan teknologi IV: peran strategis sains dan teknologi dalam membangun krakter bangsa. Bandar Lampung: Lembaga Penelitian Universitas Lampung; 2012. hlm. 865-77.

9. Subeki, Setyaningrum E, Rudiyanto W. Penggunaan brusein-A dari buah makasar (Brucea javanica) sebagai obat kanker payudara di Indonesia. Laporan penelitian hibah bersaing. Bandar Lampung: Lembaga
Penelitian Universitas Lampung; 2013.

10. Meergans T, Hildebrandt AK, Horak D, Haenisch C, Wendel A. The short prodomain influences caspase-3 activation in HeLa cells. Biochem J. 2000;349(Pt 1):135-40.

11. Hsu A, Bray TM, Helferich WG, Doerge DR, Ho E. Differential effects of whole soy extract and soy isoflavones on apoptosis in prostate cancer cells. Exp Biol Med (Maywood). 2010;235(1):90-7.

12. Yuan SSF, Chang HL, Chen HW, Yeh YT, Kao YH, Lin KH, dkk. Annonacin, a monotetrahydrofuranacetogenin, arrests cancer cells at the G1 phase and causes cytotoxicity in a Bax- and caspase-3-related pathway. Life Sci. 2003;72(25):2853-61.

13. Yu B, Sun X, Shen HY, Gao F, Fan YM, Sun ZJ. Expression of the apoptosis-related genes BCL-2 and BAD in human breast carcinoma and their associated relationship with chemosensitivity. J Exp Clin Cancer Res. 2010;29:107.

14. Subeki, Muhartono. Senyawa brusein-A dari buah makasar (Brucea javanica (L.) Merr.) sebagai antiproliferasi terhadap sel kanker payudara T47D. MKB. 2015;47(1):22-8.

15. Parton MM, Dowsett I, Smith. Studies of apoptosis in breast cancer. BMJ. 2001;322(7301):1528-32.

16. Tejasari M, Nursalim S, Djanuarsih I, Herri SS. Peran kedelai (Glycine max L.) dalam pencegahan apoptosis pada cedera jaringan hati. GMHC. 2014;2(1):15-20. 